\title{
GROWTH RESPONSE OF ONE YEAR OLD POST PLANTED Shorea leprosula SEEDLING TO VARIOUS LIGHT, UNDER 19 YEARS OLD Acacia mangium STAND
}

\author{
Heru Dwi Riyanto ${ }^{1}$
}

\begin{abstract}
Development of meranti (S. leprosula) plantation forest is limited/constrained by many factors, e.g. seed supply and seedling growth environment. The research deals with the observation of the current condition on $A$. mangium stand and did not employ any treatments. Meranti seedling was obtained from vegetative cutting (Komatsu-Forda), at one year (old) post planted meranti under $A$. mangium stands and spacing of $4 \times 2 \mathrm{~m}$, approximately two hectares of permanent sample plot (PSP) were made. In each hectare of young meranti plants with spacing $10 \times 3 \mathrm{~m}$ ( 330 seedling/ha), 9 (nine) observation plots with size $10 \times 10 \mathrm{~m}$ (6 seedlings/plot) were prepared, and placed in the middle of PSP. Totally, there were 108 seedlings available for the measurement of particular parameter, i.e. light intensity, height growth, and survival rate. Light intensity was measured by going around of $10 \times 10 \mathrm{~m}$ plot.

Result of measurement in each observation plot $(10 \times 10 \mathrm{~m}$ size $)$ rescaled that light intensity ranged about $6,55-35,2 \%$ or being equal with $4908-26568$ flux hour. Meanwhile, the best height growth response and survival rate were at $10 \%$ light intensity or over.
\end{abstract}

Keywords: Shorea leprosula, Acacia mangium stand, light intensity, height growth

\section{INTRODUCTION}

Development of meranti (S. leprosula) plantation forest is limited by e.g., seed/seedling supply and seedling growth environment. Natural Dipterocarpaceae forest has irregular fruiting season. Not every year we can harvest a lot of its seeds, but there is an unpredictable time when the natural Dipterocarpaceae forest can be so productive, known as mass flowering. Most of seedlings supplied from seeds still face with some problems, such as short period of seed viability and short period of seed storage capability. To solve this problem, vegetative cutting is one of the alternatives to be developed currently.

Growth of Dipterocarpaceae's, meranti seedling is influenced by several factors, mainly light intensity which can pass through all the way into forest floor. Light intensity factor is strongly correlated with the relative capability of genetic gain and plant physiologies for the growth in specific environment, and the capability to avoid low light intensity in general (Baker et al., 1987 in Daniel et al., 1987). Meranti is included in the plant group of Gap

\footnotetext{
${ }^{1}$ Watershed Managément Technology Research and Development Center, Surakarta
} 
Opportunist Species, (Hutchinson, 1980 in Sagala, 1985), of which species regeneration will be delayed by low light intensity (Matsune et al., 1993; Nicholson, 1979 in Sagala, 1985). How strong is light intensity needed? So far, no experts can yet give the conclusion how much light intensity is quantified.

Based on this presumption, it is necessary to conduct research on growth responses to various light intensity regarding the adaptability of meranti seedlings procured from vegetative cutting.

\section{MATERIALS AND METHODS}

This research was conducted in A-12 Compartment Benakat Research Forest, Center of Research and Development of Plantation Forest, Palembang, South-Sumatera. This research is a compartment unit for the Establishment of meranti ( $S$. leprosula) Plantation Forest by Komatsu Vegetative cutting, which grew under 19 year age of $A$. mangium stands.

\section{A. Materials}

One year old meranti ( $S$. leprosula) seedlings after their planting, and 19 - year old $A$. mangium stands.

\section{B. Methods}

Two hectares of permanent sample plot (PSP) were prepared for meranti seedlings. Each hectare (ha) of the PSP with the space of $10 \times 3 \mathrm{~m}$ or containing 330 seedlings per ha was then divided into 9 observation plots, which in size measured $10 \times 10 \mathrm{~m}$. These plots each contained 6 seedling, and further took place in the middle of PSP. Hence, totally there were about 108 seedlings to be measured/observed of their particular parameters, i.e. height growth, light intensity, and survival rate, which was measured using a meter-band, while measurement of light intensity was by going around $10 \times 10$ m plots using Minolta Digital Light Handy Type T 20.

\section{RESULT AND DISCUSSION}

\section{A. Result}

From the light intensity measurement on each $10 \times 10 \mathrm{~m}$ plot of meranti (S. leprosula) seedlings, the intensity ranged about $6,5-35,2 \%$ or being equal to $4908-26568$ flux hour. The averages of light intensity, height increment, and survival rate on each $10 \times 10 \mathrm{~m}$ plot are shown in Table 1. 
Table 1. Averages of light intensity, survival rate, height growth of one year old meranti ( $S$. leprosula) seedlings grew under the 19 year old $A$. mangium stands

\begin{tabular}{|c|c|c|c|c|c|c|}
\hline \multirow{2}{*}{$\begin{array}{c}\text { No. } \\
\text { Plots }\end{array}$} & \multicolumn{2}{|c|}{ PERMANENT SAMPLE PLOT 1 } & \multicolumn{2}{c|}{ PERMANENT SAMPLE PLOT 2 } \\
\cline { 2 - 7 } & $\begin{array}{c}\text { Light } \\
\text { Percentage }\end{array}$ & $\begin{array}{c}\text { Survival } \\
\text { Rate }\end{array}$ & $\begin{array}{c}\text { Height } \\
\text { Growth } \\
\text { Average }\end{array}$ & $\begin{array}{c}\text { Light } \\
\text { Intensity } \\
\text { Percentage }\end{array}$ & $\begin{array}{c}\text { Survival } \\
\text { Rate }\end{array}$ & $\begin{array}{c}\text { Height } \\
\text { Growth } \\
\text { Average }\end{array}$ \\
\cline { 2 - 7 } & $(\%)$ & $(\%)$ & $(\mathrm{cm})$ & $(\%)$ & $(\%)$ & $(\mathrm{cm})$ \\
\hline 1. & 6.5 & 66,7 & 30,5 & 12,8 & 100 & 29,7 \\
2. & 8,0 & 100 & 29,8 & 14,2 & 83,3 & 66,2 \\
3. & 8,7 & 83,3 & 50,1 & 16,6 & 100 & 49,6 \\
4. & 12,7 & 100 & 35,1 & 17,4 & 100 & 48,5 \\
5. & 16,6 & 100 & 45,5 & 17,8 & 100 & 66,8 \\
6. & 20,8 & 83,3 & 49,4 & 19,5 & 100 & 63,0 \\
7. & 22,5 & 100 & 60,1 & 23,8 & 100 & 49,6 \\
8. & 29,2 & 100 & 34,5 & 30,0 & 83,3 & 29,9 \\
9. & 35,2 & 100 & 65,5 & 32,9 & 100 & 38,4 \\
\hline
\end{tabular}

Concerning the homogeneity of the A. mangium stand, i.e. crown covering, stand density, etc, PSP I and PSP II were made in the same compartment.

The existing light intensity were grouped into 4 (four) light intensity classes, as seen in the following graph (Figures 1 and 2).

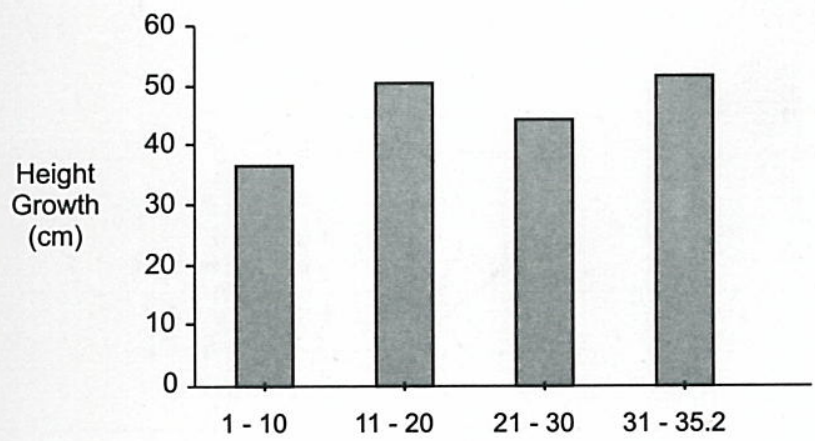

Light Intensity Classes (\%)

Figure 1. Height growth average of $S$. leprosula at various light intensity classes 
Journal of Forestry Research Vol. 3 No. 1, March 2006: 1 - 6

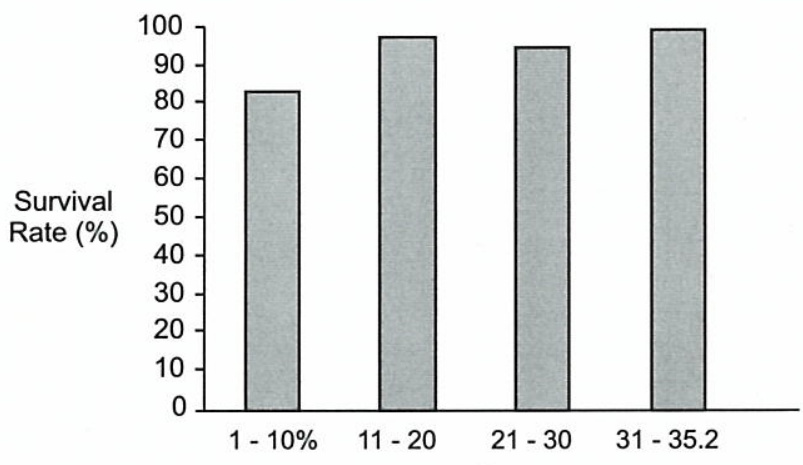

Light Intensity Classes (\%)

Figure 2. Survival rate of $S$. leprosula at various light intensity classes

The correlation between the individual height increment of individual seedling and its light intensity is shown in the following scattered diagram (Figure 3).

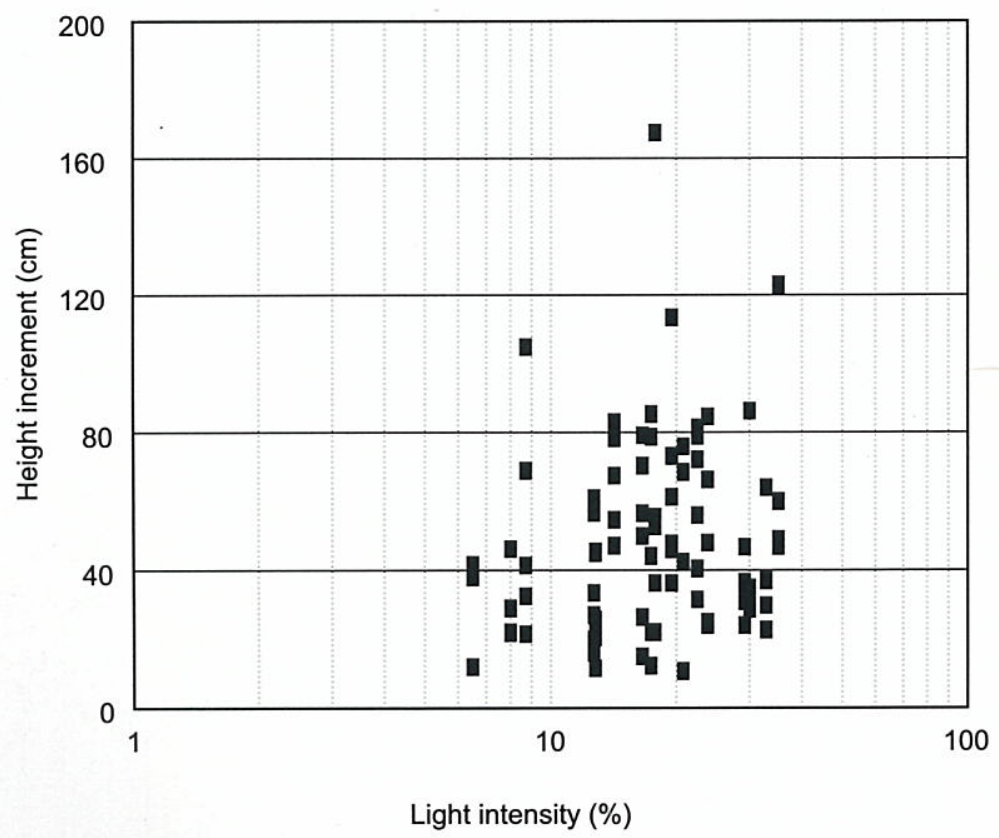

Figure 3. Scattered diagram of height growth versus light intensity 


\section{B. Discussion}

Almost all of meranti (Shorea sp) species needs the shading for their first (initial) growth (Nicholson, 1979 in Sagala, 1985). So far, there is no definitive explanation about the extremely strong intensity of light that can cause mortality of meranti seedlings or whether it can happen due to just impact. For example, too strong full sunlight can make the seedling sites become dry. This dry condition further renders the soil and litter becoming hotter and hotter thereby causing the death of mycorrhizae fungi which otherwise can perform the obligate symbiosis with meranti (Dipteriocarpaceae) seedlings. The (ideal) soil temperature for mycorrhizae growth is around $18-27^{\circ} \mathrm{C}$ (Palmer, 1971; de Huster, 1974 and Anwar, 1990 in Iskandar and Abdurrahman, 1997) while the temperature higher than $35^{\circ} \mathrm{C}$ can make the mycorrhizae die (Suhardi, 1992 in Iskandar and Abdurrahman, 1997).

Some research showed that meranti seedlings had their best growth on light intensity of $30-50 \%$ in the open land or from the full light, (Sutisna, 1995 in Riyanto, 1999). Conversely, Kusnandar (2001) reported his observation results that meranti seedlings have poor growth on the site with full light intensity (open land). As the experts have mentioned previously, meranti is a Gap Opportunist Species, of which the regeneration and growth will be delayed by low light intensity. This can be explained by the observation results in the Figures 1, 2, and 3 that showed that the best growth of meranti seedlings was at $30 \%$ of light intensity or over, or in general better growth of the seedlings affords at $10 \%$ intensity. Not optimal growth of meranti seedlings at light intensity under $10 \%$ was caused by the fact that such intensity did not suffice enough to reach the minimum need for the photosynthesis process (Whitmore, 1984 in Daniel et al., 1987). From the discussion above, it can be concluded that critical light intensity is needed by meranti seedlings to support photosynthesis process for their growth. Their incapability to accept full and direct light intensity is related to the species genetic gain necessary for their growth. They have to perform symbioses with fungi. Unfortunately, the full and direct light intensity can kill the fungi, therefore the host plants will suffer the deficiency in particular nutrients provided by the fungi.

\section{CONCLUSION}

1. Light intensity which comes through all the way into forest floors influences height growth and survival rate of meranti seedlings, therefore for successful meranti plantation forest establishment light intensity factor has to be considered.

2. Result of measurement on light intensity in each $10 \times 10 \mathrm{~m}$ observation plot of meranti seedlings revealed that it ranged about 6,55 - 35,2\% or being equal with 4908 - 26568 fluxhour. The better growth of the seedlings occurred in general at the intensity over $10 \%$. As such, it would also afford survival rate of meranti seedlings. 


\section{REFERENCES}

Daniel, T.W., J.A. Helms and F.S.Baker. 1987. Prinsip-Prinsip Silvikultur. Gadjah Mada University Press, Yogyakarta.

Iskandar, A.M. and Abdurrahman. 1997. Studi status mikoriza Arbuskula pada hutan rawa gambut. Seminar on Mycorrhizae, Samarinda.

Kusnandar, E. 2001. Pengembangan tanaman meranti dengan bibit asal setek Komatsu. Laporan Penelitian Balai Teknologi Reboisasi Palembang (Unpublished).

Matsune. K., T. Kojima, H. Yagi, R. Soda, N. Kobayashi, and S. Sasaki. 1993. Growth responses of Dipterocarp seedlings to various light condition in the field. Dalam Proceedings of Jogyakarta Workshop. BIO-REFOR.

Riyanto, H.D. 1999. Pengaruh intensitas cahaya dan pemupukan terhadap permudaan Dipterocarpaceae di Jambi. Dalam Prosiding Ekspos Hasil Penelitian dan Pengembangan BTR Palembang.

Sagala, A.P.S. 1985. Penyempurnaan tegakan bekas tebangan pembuatan hutan tanaman meranti dan pengendalian perladangan berpindah. Departemen Kehutanan Direktorat Jenderal Reboisasi Dan Rehabilitasi Lahan. Balai Teknologi Reboisasi, Kalimantan Selatan.

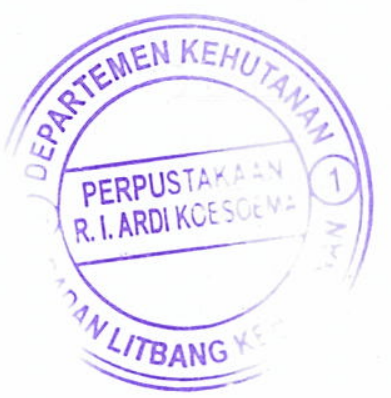

